\title{
Toksyczny związek: przemocowa nauka i filozofia nieasertywna. Recenzja książki Filozofia i nauka: trudne związki. Metallmann - Witkiewicz - Gawecki
}

Autor: Maciej Dombrowski

Wydawca: Wydawnictwo Naukowe Uniwersytetu

Mikołaja Kopernika

Rok wydania: 2011

Liczba stron: 278

Błażej Brzostek

Projekt Avant

jahyenawa@avant.edu.pl

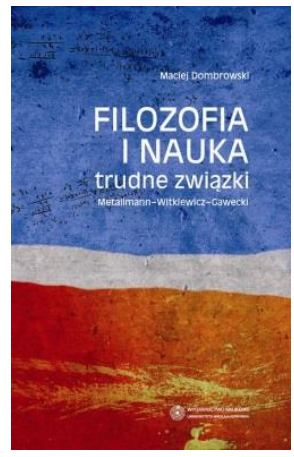

\begin{abstract}
Abstrakt
Autor omawia książkę Macieja Dombrowskiego w kontekście refleksji przynależnej do nauki oraz filozofii, charakteryzującej koncepcje Joachima Metallmanna, Stanisława Ignacego Witkiewicza i Bolesława Józefa Gaweckiego.

Słowa kluczowe: Metallmann; Witkiewicz; Gawecki; filozofia; nauka.

Filozofia i nauka: trudne związki. Brzmi to nieco jak tytuł poradnika małżeńskiego, bo też istotnie, filozofia i nauka to para trudna, o skomplikowanych relacjach. Niektórzy widzą w tym duecie flagowy przykład związku toksycznego i alergicznie reagują na samo ich zestawienie w jednym akapicie. Są też tacy, którzy uważają, że warto rozmawiać i wspólnie pracować nad kompromisem, ponieważ, czy tego chcą, czy nie, filozofowie i naukowcy (przyrodnicy?) są związani szczególnego rodzaju sakramentem. Rolę terapeuty w tej odsłonie dyskusji przyjął Maciej Dombrowski. W opublikowanej przez Wydawnictwo Naukowe Uniwersytetu Mikołaja Kopernika pracy porusza wiele ciekawych filozoficznych wątków, mimo iż jej zakres został ograniczony do trzech wyłącznie filozofów i jednego głównego zagadnienia: problemu relacji między filozofią a nauką oraz możliwości przedstawienia szkicu rozwiązania tego problemu, inspirowanego kombinacją poglądów owych filozofów: Joachima Metallmanna, Stanisława Ignacego Witkiewicza i Bolesława Józefa Gaweckiego.
\end{abstract}


Na początku wyjaśnienia domaga się sam problem relacji filozofii i nauki, a przede wszystkim jego aktualność. W XX wieku faktycznie zagadnienie stosunku wiedzy naukowej (i metody) do wiedzy filozoficznej było niezmiernie ważne: nauki empiryczne już od dawna święciły ogromne sukcesy, ich metoda (eksperyment, narzędzia matematyczne, przewidywalność itd.) dawała rezultaty, których filozofia dać nie mogła, nie wspominając już o powracających niczym refren „kompromitacjach” metafizyki. Ciągłe doskonalenie narzędzi prowadziło do przejmowania przez naukę zagadnień, którymi zajmowali się dotychczas filozofowie. Dzisiaj Nauka i Naukowcy spod znaku mikroskopu to największe autorytety na świecie, których posłuchamy w każdej, dającej się zmierzyć i zważyć, dziedzinie życia. W tym właśnie kontekście rysuje się problem autonomii wiedzy filozoficznej. Zresztą już takie postawienie sprawy mówi dużo o tych relacjach; otóż nauka nie musi obawiać się o swoją przyszłość, filozofia - inaczej: jest przez nią zagrożona i widać to między innymi w fakcie, że to filozofowie raczej szukają swojego miejsca na współczesnej mapie wiedzy, a nie pewni siebie naukowcy. Należy przy tym zaznaczyć, że sama ta kwestia jest problemem filozoficznym, i jeżeli w jakimś stopniu zajmuje naukowców, to raczej po pracy, przy kawie. Nie można się zatem spodziewać po filozofach „rychłego” rozwiązania. Na szczęście nastała „moda” na interdyscyplinarność: zespoły interdyscyplinarne, kierunki interdyscyplinarne, badania, myślenie, mówienie, etc. Filozof w takim zespole zajmuje ważne miejsce i raczej nie powinno go tam zabraknąć. Czyżbyśmy więc odłożyli spory na bok i po prostu zaczęli razem pracować? Wydaje się, choć to tylko hipoteza, że problem jednak został ostatecznie rozwiązany, czego przykładem są właśnie badania interdyscyplinarne. Cóż, jeżeli jednak jeszcze nie został rozwiązany, to jako problem filozoficzny jeszcze długo będzie aktualny.

Maciej Dombrowski stara się nas przekonać, że filozofia jest działalnością racjonalną i należy bronić jej autonomii i prawa do istnienia. Często mamy do czynienia z dwiema postawami wobec problemu demarkacji wiedzy naukowej i filozoficznej. Pierwsza będzie się starała unaukowić filozofię, przejąć metody nauk szczegółowych oraz precyzję ich języka, taką postawę prezentowali (prezentują?) filozofowie analityczni. Druga postawa unika problemu przez zupełne odcięcie się od nauki, filozofia ma swoje metody, problemy, słowniki. Żadne $\mathrm{z}$ tych stanowisk nie jest satysfakcjonujące dla Autora, ponieważ może okazać się „samobójcze dla kondycji filozofii”. Są to oczywiście skrajności, między nimi jest dużo miejsca na dialog i właśnie prezentacja myśli trzech filozofów i ich stosunku do zagadnienia ma ten dialog ułatwić. Pogodzili oni filozofię i naukę, przydając każdej autonomię i pozwalając im oddychać wspólnym powietrzem. Wskazanie takiej postawy dialogu jest głównym celem książki. Ponadto Autor stara się przekonać, iż oryginalne koncepcje omawianych filozofów można zaliczyć do filozofii przyrody. Ale - co ważne - kompilacja ich myśli może zostać, zdaniem Autora, połączona w program, „który może być rozwijany współcześnie”. 
Zdaniem Autora, Joachim Metallmann jest jednym z najważniejszych polskich filozofów nauki. Nie zdobył co prawda takiej popularności jak Ludwik Fleck, wyprzedzający konstruktywizm, chociaż i on wyprzedzał w swoich pracach późniejsze badania, szczególnie te dotyczące emergentyzmu. Metallmanna podejście do nauki było więcej niż życzliwe: sama nauka jest najdoskonalszym narzędziem poznania, jej wyniki są pewne. Dlatego też chciał on uprawiać filozofię w sposób naukowy, często odwołując się do bardzo mu dobrze znanych fizyki i biologii.

Na naukę składają się różne twierdzenia o rzeczywistości oraz operacje na tych twierdzeniach przeprowadzane, łącznie z zestawianiem ich ze zdaniami obserwacyjnymi, w wyniku czego dostajemy obiektywną wiedzę o rzeczywistości. Twierdzenia ogólne produkowane są dzięki indukcji, która mimo filozoficznej krytyki jest najważniejszym narzędziem w repertuarze naukowców. Zakładając podobieństwo przyszłych przypadków do przeszłych, nauka nie tylko sama się rozwija, ale także umożliwia postęp techniczny. Filozof ten świadomy jest jednak wielu problemów, jakie napotyka nauka, szczególnie dotyczących prawdziwości zdań nauki (klasyczna definicja prawdy prowadzi, zdaniem Metallmanna, do nierozwiązywalnych aporii) czy ich intersubiektywnej komunikowalności. Filozofia w tym kontekście, jak mówi Metallmann, „staje się coraz wyraźniej i niedwuznacznie funkcją nauki, tak iż filozofia pewnej epoki okazuje się odpowiednikiem nauki właśnie tej epoki”. Nie można oddzielać grubą kreską nauki od filozofii; jest ona oczywiście źródłem zagadnień, które przejmuje nauka, ale odpowiedzi tej drugiej nigdy nie będą satysfakcjonować filozofii, pyta ona bowiem o istotę, wartości i cele. Są więc nauka i filozofia dziedzinami różnymi: zadającymi inne pytania i angażującymi inne metody uzyskiwania odpowiedzi na nie. Mimo to nauka wpływa na filozofię, dając jej swoje wyniki oraz pojęcia (także metody). Filozofia analizuje jej strukturę, metodologię, założenia, pojęcia oraz syntetyzuje jej wyniki. Zbliżenie filozofii i nauki dokonuje się tu poprzez przejmowanie przez filozofów metod badawczych i ścisłości opisu, jakie znamy z fizyki. Rezultatem tego byłoby unaukowienie filozofii, ale $\mathrm{w}$ tym zakresie podejmowanych problemów, w jakim jest to możliwe, ponieważ nie wszystkie mogą zostać podjęte metodą naukową.

W pracy napotykamy również dość pobieżnie skreślone wyniki rozważań Metallmanna nad emergencją, nie jest to jednak zarzut, bowiem ta problematyka jest już w znacznej części opracowana (zob. prace Janusza Mączki), tym bardziej, że sam Metallmann nie opracował tego zagadnienia w sposób szczegółowy. Poza tym nie wydaje się, aby miało to wielkie znaczenie dla dowiedzenia tezy postawionej przez Autora na wstępie. Pojawienie się wątku emergentyzmu wpływa dodatnio na całą pracę, pokazuje także, że Autor bardzo sprawnie operuje wieloma słownikami filozoficznymi. 
Filozofia i nauka żyją u Metallmanna w harmonii. Filozofia jest tu funkcją nauki, ale posiada swój własny rezerwuar problemów i metod, które są niedostępne „aparaturze” naukowej. Jest również autonomiczna, ponieważ założenia nauk szczegółowych mają już charakter metafizyczny, którego analiza nie może stać się przedmiotem tych nauk, ale filozofii właśnie.

Joachim Metallmann nie jest filozofem popularnym, chociaż uczestniczył, jako jeden z niewielu Polaków, aktywnie w dyskusji nad ogromnym projektem filozofii Whiteheada. Jako pierwszy w Polsce rozwijał oryginalnie koncepcję emergentyzmu, a także antycypował koncepcję strukturalizmu. Autor więc chlubnie dopisuje się do dość krótkiej listy opracowań twórczości krakowskiego filozofa, popularyzując jego myśl.

Aktywność twórcza Stanisława Ignacego Witkiewicza, jej rozmach i jakość, słusznie budzą podziw, ale to nie malarstwo ani literatura były dla niego najważniejsze, gdyż za najważniejszy w swojej twórczości uznawał dorobek filozoficzny. A był on niemały, wszystkie jego prace poświęcone filozofii zamykają się w liczbie dwudziestu trzech. Przez brak afiliacji akademickich często bywa lekceważony - niesłusznie, jak przekonuje Autor „ze względu na rzadką w polskiej filozofii tendencję maksymalistyczną, połączoną z głęboką analizą, na której zostaje ona oparta” (Dombrowski 2011: 191).

Nauka (a za taką głównie uznaje fizykę), zdaniem Witkacego, jest zależna od tak zwanego poglądu życiowego, czyli naszego codziennego nastawienia i praktycznego pojmowania rzeczywistości, na przykład poprzez praktyczne przesądy. Takie pojęcia fizyczne jak siła czy masa, uwikłane w nasze potoczne poglądy, dają się jednak wyrazić w języku psychologizmu, który był przez niego pojmowany jako dziedzina filozofii. Co więcej, psychologizm miał tłumaczyć tak pogląd życiowy, jak i terminy fizykalne. Nauka jest tu tylko wiedzą prawdopodobną, opartą na statystyce, daleką od prawdy absolutnej. Jest ona opisem zaledwie wycinka rzeczywistości i nie może redukować wszystkich jej aspektów do własności fizycznych. Fenomenu życia nie można opisać w sposób ilościowy, ponieważ między rzeczą, zjawiskiem a organizmem żywym istnieje różnica natury jakościowej. Percepcja również nie może zostać sprowadzona do opisu ilościowego ze względu na „mojość' wrażenia. W kontekście myśli Witkacego Maria ze znanego przykładu byłaby dość zaskoczona po wyjściu z laboratorium. Dlatego też nauka stanowi pewne zagrożenie dla filozofii; uzyskując szerokie poparcie, może swobodnie zagarniać obszary przeznaczone dla filozofów, ponadto może wyrokować o jasności czy niejasności wywodów filozoficznych, co w skrajnych przypadkach przybierać może formę linczu. Nie jest jednak Witkacy wrogiem nauki. Ma ona po prostu inne zadania niż filozofia, nie może stać się wiedzą ogólną o strukturze bytu, jest raczej wiedzą lokalną, przejściową konstrukcją, i jako taka może wejść w skład Ontologii Ogólnej. 
Filozofia jest dla Witkiewicza projektem totalnym. Ma odnajdywać w rzeczywistości stosunki konieczne i zmierzać w stronę zdobycia całej wiedzy o rzeczywistości. Mimo to Witkacy daje poszczególnym propozycjom ontologicznym zaledwie status bardziej lub mniej prawdopodobnych, w zależności od ich radzenia sobie z klasycznymi problemami. Kwestia relacji między nauką a filozofią zostaje zawarta w jego Ontologii Ogólnej. Można powiedzieć, że nauka i filozofia „atakują” rzeczywistość z różnych stron, chodzi więc o to, aby te różne sposoby jej ujmowania pogodzić w jednym najbardziej ogólnym poglądzie, w którym z kolei zawierać się będą wszystkie pomniejsze „poglądziki” na rzeczywistość. Taka architektura naszej wiedzy jest Ontologią Ogólną, czyli po prostu filozofią, którego to terminu, już wyświechtanego, pragnie Witkacy się pozbyć. Filozofia zatem „bada stosunki zachodzące między poglądami implikowanymi przez tę rzeczywistość i stara się je uzgodnić" (Dombrowski 2011: 143), nauka zaś bada samą rzeczywistość jako taką. Jak twierdzi Bohdan Michalski, filozofia Witkacego bada i uzgadnia różne poglądy na rzeczywistość, co prowadzić ma ostatecznie do poznania bytu (Michalski 1979). Pogodzenie nauki i filozofii opiera się w tym programie na filozofii, spinającej różne wymiary badań materii martwej i żywej, filozofii będącej fundamentem wiedzy. Tak oto, zgrzebnie przedstawiając, Witkiewicz pozwala istnieć nauce i zaprasza ją do budowania Ontologii Ogólnej, ale pod nadzorem filozofii.

Bolesław Józef Gawecki, podobnie jak Metallmann, nie jest filozofem dobrze znanym, chociaż jego dorobek jest dość pokaźny ilościowo oraz (na gruncie polskim) jakościowo. Nie ma zbyt wiele opracowań mu poświęconych, dlatego też omawiana praca nosi cechy wręcz unikatowości.

Zdobywanie wiedzy naukowej, według Gaweckiego, zasadza się na metodzie i dąży do systemowego wyjaśniania rzeczywistości. Przez system rozumie on układ intersubiektywnie sprawdzalnych zdań o faktach i związkach logicznych. Nauki formalne (matematyka, logika) nie badają faktów, ich wyniki posiadają jednak cechę pewności, obowiązującą wewnątrz danego systemu aksjomatycznego. Fakty badają nauki realne, w skład których wchodzą zarówno nauki szczegółowe, jak i humanistyczne; różnią się co do traktowania owych faktów - odpowiednio - w sposób ilościowy i jakościowy. Nauki realne obarczone są skazą prawdopodobieństwa, Gawecki nie ma więc wątpliwości co do ich niedoskonałości: bierze się ona ze stosowania indukcji jako głównej metody naukowej. Postawienie hipotezy jest dla niego najważniejszym etapem badań: „przyroda nie odpowiada na pytania źle postawione”. Efektem pracy naukowca są prawa, czyli opis związków między faktami; następnym etapem jest budowanie teorii, czyli konstrukcji składającej się z wielu poszczególnych praw.

Nauka, mimo sukcesów, nie potrafi jednak objąć całości rzeczywistości, pozostaje bowiem obszar odporny na jej modus operandi, i tu znajduje Gawecki miejsce dla filozofii. Sama metoda ilościowa nie może być zastosowana do 
wszystkich własności badanego zjawiska, destyluje się więc wybrane, mierzalne własności i poddaje reżimowi statystycznemu. Nauka coraz częściej musi uciekać się do fragmentaryzacji obiektów swoich badań; wysoka specjalizacja w nauce jest oczywiście nieunikniona, ale nie ocenia Gawecki tego zjawiska pozytywnie. Nauka przez taką decentralizację traci obraz całości, niemożliwe staje się przyswojenie przez jednego badacza choćby części aspektów danego zagadnienia. Rozczłonkowany obraz rzeczywistości ma na powrót połączyć filozofia. Posługując się Kantowskim podziałem na poznawalne zjawiska i rzeczy same w sobie, Gawecki powierza te pierwsze nauce, podczas gdy filozofia ma pracować $\mathrm{w}$ dziedzinie noumenów. Badania arche, ukrytej za zjawiskami, prowadzić mogą do różnych (nieweryfikowalnych) propozycji co do natury bytu, co po prostu jest „przeznaczeniem filozofii, od jej początków w starożytnej Grecji, aż po domniemany kres” (Dombrowski 2011: 211). Nie jest to oczywiście jej jedyne zadanie; jest ona głównie krytyką poznania i wiedzy. Wspomniana decentralizacja i specjalizacja zagraża całościowemu obrazowi wiedzy, filozofia zaś próbuje ten obraz scalić poprzez syntezę poznania, „ostatecznie wiąże w całość liczne zjawiska i prawa opisane przez przyrodników, interpretując je swoiście i dodając własne hipotezy wykraczające poza naukę" (Dombrowski 2011: 212). Całość dać ma system metafizyczny, obejmujący wszystkie dziedziny filozoficzne, który prezentować będzie obraz świata $\mathrm{w}$ danym momencie historycznym, uwzględniający zarówno wiedzę w danym momencie, jak i hipotezę na temat arche.

Cała praca robi dość imponujące wrażenie, rekonstrukcja poglądów tych trzech filozofów jest ścisła - w ramach celu pracy - i niezwykle przejrzysta. Wybór Mettalmanna, Witkacego i Gaweckiego okazuje się logiczny, prowadzi bowiem, upraszczając, od postawy pronaukowej przez profilozoficzną, aby na końcu, w poglądach Gaweckiego, wygasić konflikty i pogodzić je obie. Otrzymujemy w końcu propozycję, która mieści się między unaukowieniem filozofii a odrzuceniem przez nią sporu. Autor, dokonując krótkiego podsumowania, szkicuje koncepcję, wyrosłą z połączenia myśli omawianych filozofów, odnoszącą się do współcześnie uprawianej filozofii przyrody. Korzystając z ustaleń Zygmunta Hajduka, wskazuje Autor na taki typ uprawiania filozofii przyrody, który unikałby zarówno utonięcia w nauce, jak i w zupełnym jej nierespektowaniu. Opierałby się na założeniu, iż filozofia przyrody daje wiedzę o rzeczywistości, która od wiedzy naukowej różni się aspektem, nie jest $\mathrm{z}$ nią jednak sprzeczna, ponieważ pozostaje z nią w ciągłym kontakcie. Filozofia ma także podstawy do syntetyzowania wyników nauk szczegółowych, wychodząc jednocześnie poza same te wyniki w stronę pewnych hipotez metafizycznych. Intuicja Autora co do współczesnego zastosowania takiej koncepcji filozofii przyrody wydaje się trafna, jak sam zresztą zauważa, są filozofowie bliscy takiego ujęcia (Anna Lemańska). Konflikt między filozofią a nauką zostaje tu zażegnany; jak się okazuje, takie rozwiązanie można wypracować bez orzekania rozwodu o wyłącznej winie. 
Całość należy ocenić jako solidną (w tej ocenie pomaga rzut oka na bibliografię): rekonstrukcje są ścisłe i przejrzyste, w czym pomaga jasny styl Autora. To ważne, że powstają prace tego typu, przede wszystkim popularyzujące mniej znanych polskich filozofów. Ale co warto podkreślić: nie jest to wyłącznie praca czysto historyczna. Autor przy okazji rekonstrukcji prowadzi aktywne badania analityczno-krytyczne. Dowodzi to, że uprawianie historii filozofii w formie, w jakiej robi to Autor, jest inspirujące i atrakcyjne w kontekście zagadnień współczesnych; nie prowadzi ono do zmurszenia czy przesłonięcia nowych, oryginalnych rozwiązań. Wręcz przeciwnie: pokazuje, jak można twórczo czerpać z historii.

\section{Literatura}

Dombrowski, M. 2011. Filozofia i nauka: trudne związki. MetallmannWitkiewicz-Gawecki. Toruń: Wydawnictwo Naukowe Uniwersytetu Mikołaja Kopernika.

Michalski, B. 1979. Polemiki filozoficzne Stanisława Ignacego Witkiewicza. Warszawa: Wydawnictwo PIW. 